\title{
Ground beetles (Coleoptera; Carabidae) as an indicator of ongoing changes in forest habitats due to increased water retention
}

\author{
Emilia Ludwiczak ${ }^{\text {Corresp., } 1}{ }$, Mariusz Nietupski ${ }^{1}{ }^{1}$ Agnieszka Kosewska ${ }^{1}$ \\ ${ }^{1}$ Department of Entomology, Phytopathology and Molecular Diagnostics, University of Warmia and Mazury in Olsztyn, Olsztyn, Poland \\ Corresponding Author: Emilia Ludwiczak \\ Email address: emilia.ludwiczak@uwm.edu.pl
}

This study, concerning the epigeic fauna of carabid beetles (Coleoptera; Carabidae), was conducted in the north-east of Poland, in an area which is part of the Dąbrówka Forest Subdistrict and has been included in the "Small water retention program for the Province of Warmia and Mazury in 2006-2015". The purpose of the study was to assess the impact of the water retention implemented within the framework of the above program on assemblages of ground beetles. These insects are highly sensitive to any anthropogenically induced transformations. This analysis was based on the interactions among the analyzed insects caused by changes occurring in their habitat. During the three-year study, 5807 specimens representing 84 species were captured. The water storage had a significant influence on the structure of the Carabidae assemblages. Before the earthworks were constructed for the project, the beetle assemblages had comprised a large group of xerophilous species, whereas after the small retention reservoirs had been created, an increase in the contribution of hygrophilous species was noticed. The results indicate that the retention works cause alterations in the water and environmental conditions of the habitats, and thereby effect changes in the composition of Carabidae assemblages. Moreover, modification in water relations within a habitat causes long-term changes in the structural and functional diversity of the beetles. 


\section{Ground beetles (Coleoptera; Carabidae) as an}

\section{2 indicator of ongoing changes in forest habitats due to}

\section{3 increased water retention}

5 Emilia Ludwiczak ${ }^{1}$, Mariusz Nietupski ${ }^{1}$, Agnieszka Kosewska ${ }^{1}$

$6 \quad{ }^{1}$ Department of Entomology, Phytopathology and Molecular Diagnostics, University of Warmia

7 and Mazury in Olsztyn, Olsztyn, Prawochenskiego 17, 10-720, Poland

8 Corresponding Author:

9 Emilia Ludwiczak ${ }^{1}$,

10 Prawochenskiego 17, Olsztyn, 10-720, Poland

11 Email address: emilia.ludwiczak@uwm.edu.pl

\section{Abstract}

14 This study, concerning the epigeic fauna of carabid beetles (Coleoptera; Carabidae), was

15 conducted in the north-east of Poland, in an area which is part of the Dąbrówka Forest

16 Subdistrict and has been included in the "Small water retention program for the Province of

17 Warmia and Mazury in 2006-2015". The purpose of the study was to assess the impact of the

18 water retention implemented within the framework of the above program on assemblages of

19 ground beetles. These insects are highly sensitive to any anthropogenically induced

20 transformations. This analysis was based on the interactions among the analyzed insects caused

21 by changes occurring in their habitat. During the three-year study, 5807 specimens representing

2284 species were captured. The water storage had a significant influence on the structure of the 
23 Carabidae assemblages. Before the earthworks were constructed for the project, the beetle

24 assemblages had comprised a large group of xerophilous species, whereas after the small

25 retention reservoirs had been created, an increase in the contribution of hygrophilous species was

26 noticed. The results indicate that the retention works cause alterations in the water and

27 environmental conditions of the habitats, and thereby effect changes in the composition of

28 Carabidae assemblages. Moreover, modification in water relations within a habitat causes long-

29 term changes in the structural and functional diversity of the beetles.

31 Keywords: Bioindicators; Forest Peat Bog; Species Diversity; Carabid Beetles.

1. Introduction

Water, as the principal component modeling the natural environment, plays a significant role in shaping forest ecosystems, in the sense of being both a habitat-forming element and a factor which ensures the stability, sustainability and diversity of habitats (Pierzgalski, 2008; Blumenfeld et al., 2010; Koralay \& Kara, 2018). Any aberrations from the natural water regime, such as periodic water deficits or excesses, are events that have an adverse effect on the whole ecological system (Rulik \&White, 2019). Such irregularities can be a consequence of erroneously implemented water retention or naturally occurring hydrological and meteorological

41 processes (Liberacki \& Szafrański, 2013; Miler et al., 2013; Kędziora et al., 2014).

As mentioned by Mioduszewski (2010), in compliance with the Framework Water

43 Directive of the European Union and because of the occurrence of water deficits in the entire

44 European Union, all member countries are obligated to maintain an inventory and to protect 45 ecosystems that have an impact on the shaping of proper water balance in nature. They are also 
46 required to implement measures to counteract water deficits by improving the retention capacity

47 of the biosphere. In order to take full advantage of forest ecosystems, complex actions are

48 undertaken to decelerate the circulation of water in the catchment while preserving the natural

49 landscape (European Environment Agency, 2015). Such measures, called forest retention, are

50 modeled after natural processes occurring in the natural environment (Gustafsson et al., 2012).

51 By restoring the natural retention properties of ecosystems, and thereby improving the

52 availability of water, it is possible to enhance the diversity of flora and fauna in the habitat

53 (Hansson et al., 2005; Nietupski, Kosewska \& Ciepielewska, 2007; Janusz et al., 2011;

54 Kosewska \& Nietupski, 2015).

The modifications which occur in areas where water retention has been introduced can be assessed by analyzing the responses of living organisms. Both intra- and inter-species structures of dependencies between organisms and the area they inhabit provide valuable information about the natural environment (Mc Geoch, 1998; Gerlach, Samways \& Pryke, 2013). Effective indicator species used in the monitoring of the natural environment are beetles (Coleoptera;

60 Carabidae) living on the surface of the earth (epigeic) (Tözsér et al., 2019). These insects, as

61 bioindicators of the condition of the environment, are characterized by high sensitivity to

62 changing habitat conditions, especially changes in moisture content. This means that their

63 observation can provide specific data about the current state of the ecosystem in which they live

64 (Rainio \& Niemelä, 2003; Avgin \& Luff, 2010; Koivula, 2011; Kotze et al., 2011, Bednarska et 65 al., 2018).

66 The aim of this study was to answer the following research hypotheses: 1) long-term

67 modifications of the habitat water relations affect changes in ground beetle diversity, causing the 68 disappearance of xerophilous species and the increase of hygrophilic species, 2) the designated 
69 transects differ in quantitative and qualitative values for the carabidofauna caught, 3) retention

70 works cause the disappearance of rare Carabidae species found on the Red List of endangered

71 animals in Poland (Pawłowski, Kubisz \& Mazur, 2002).

2. Materials \& Methods

73

74

75

\section{Study area.}

The study was completed in north-eastern Poland, in the Province of Warmia and Mazury, in the Dąbrówka Forest Subdistrict (UTM DE 66). Letter from the Olsztyn Forest District confirming the consent to make the area available, sent to the PeerJ publisher.

Entomological observations were carried out on an area formerly used for farming and then afforested and turfed. Two study sites were selected, characterized by different moisture conditions and located at a different distance to retention water reservoirs (' $a$ ' and ' $b$ ') created as part of the Programme of small retention for the Province of Warmia and Mazury in 2006-2015 (figure 1) (www.sporol.warmia.mazury.pl). The first study site was located 128 meters from a forest road, $36 \mathrm{~m}$ from retention water reservoir ' $\mathrm{a}$ ', and $62 \mathrm{~m}$ from retention water reservoir ' $\mathrm{b}$ '. The second study site was situated at a distance of $100 \mathrm{~m}$ from the first , $47 \mathrm{~m}$ from the forest road, 39 m from reservoir 'a' and 15 meters from reservoir 'b' (Forest Data Bank, 2019). Both study areas were characterized by similar habitat conditions. Three transects were chosen at each study site: transect $\mathrm{A}$ - on a waterlogged peat meadow, with the highest moisture content; transect B - an ecotone between the peat meadow and a forest, located $20 \mathrm{~m}$ away from transect A, and characterized by lower water abundance; transect $\mathrm{C}$ - situated in a pine forest, 20 meters away from transect B, with the lowest moisture content.

The area covered by extensive meadow was dominated by peat soils of transitional peatland with the soil moisture content classified as a very wet, and very acid reaction. At both 
92 study sites, the meadow was adjacent to a ten-year-old mixed coniferous forest with the

93 dominant species being common pine (Pinus sylvestris L.). This area was underlain mostly by

94 Brunic Arenosols with the soil moisture content classified into the category: fresh wet (Forest

95 Data Bank, 2019).

\section{Data collection.}

The water retention project in the Dąbrówka Forest Subdistrict within the framework of

the program mentioned above started in 2010 with a design phase, and was continued in the form of earthworks in 2011. The comprehensive project consisted of new water retention reservoirs

101 (www.olsztyn.olsztyn.lasy.gov.pl).

Studies on beetles of the Carabidae family were conducted in 2009, 2012 and 2013. The

first entomological observations were made prior to the retention works connected with the

project's implementation. The main purpose of the investigations carried out in 2009 was to

make an assessment of the original state of Carabidae assemblages in the area designated for the

project. The research continued in 2012 and 2013 after the hydro-technical works had been presence of the analyzed beetles.

In 2009, the field research began on 21 April and finished on 22 September (153 days). In

110 2012, the field research was carried out from 27 April to 26 October (181 days), and in 2013 it

111 lasted from 25 April to 9 October (166 days).

112 In 2009, traps were placed at study site I, linearly, in 3 transects (A, B, C). In each

113 transect, there were 5 traps spaced at 10 meters (15 traps in total) (figure 1). The position of

114 research study site I in 2009 was chosen intuitively as the exact location of the planned retention 
115 reservoirs was not known at that time. After the earthworks had been completed, the

116 entomological observations were continued (in 2012 and 2013) in the area chosen in 2009.

117 However, when the retention changes had been made, the research area was expanded by adding

118 a second research study site, located to the east of the retention reservoirs. In 2012 and 2013,

119 traps were dug at both study sites, 15 traps in each, set up in 3 rows and at the same 10-meter

120 distance as in 2009 (30 traps in total) (figure 1).

121 A modified Barber traps method was used for beetle capture, caught into containers with

122 a capacity of $500 \mathrm{ml}$ and a height of $12 \mathrm{~cm}$ (Barber, 1931). The containers were filled up to $1 / 3$

123 with a solution of ethylene glycol including a small amount of detergent to decrease the surface

124 tension. The traps were dug in level with the ground surface and emptied regularly every 14

125 days, collecting the entomological material and replacing the preserving solution.

126 Evaluation of meteorological conditions was based on measurements and observations

127 carried out at the Meteorological Station in Olsztyn. Values of the mean annual air temperature

128 during the three years of the study fluctuated only a little $\left(7.7^{\circ} \mathrm{C}\right.$ in $2009,7.5^{\circ} \mathrm{C}$ in 2012 and 7.8

$129{ }^{\circ} \mathrm{C}$ in 2013). The average sum of atmospheric precipitation during the three years of the study

130 was $629 \mathrm{~mm}(604 \mathrm{~mm}$ in 2009, $700 \mathrm{~mm}$ in 2012, $582 \mathrm{~mm}$ in 2013) (Central Statistical Office in

131 Poland, 2010; 2013; 2014).

\section{Data analysis.}

Species diversity and abundance of captured beetles were expressed in real numbers of

134 caught specimens and species. The most popular tool, i.e. the Shannon index (Shannon-Weaver,

135 1949), was used to evaluate the biodiversity of the beetles, while the assessment of any

136 deviations was based on mean individual biomass (MIB) (Szyszko et al., 2000). 
The ecological analysis was carried out using the following indicators: trophic group,

138 phenology, hygropreferences and habitat types (trophic group - (hemizoophages (Hz), small

139 zoophages $(\mathrm{Sz})$ : with a body length of no more than $15 \mathrm{~mm}$, large zoophages (Lz): with a body

140 length over 15 mm) (Leśniak, 1985; Aleksandrowicz, 2004; Kosewska, Nietupski \&

141 Ciepielewska, 2007), phenology - (spring breeders (Sb), autumn breeders (Ab)) (Larsson, 1939;

142 Thiele, 1977), hygropreferences - (xerophilous (Xe), mesophilous (M), hygrophilous (H))

143 (Thiele, 1977; Aleksandrowicz, Pakuła \& Mazur, 2008), habitat types - (forest (F), open area

144 (Oa), peat bog $(\mathrm{Pb})$, eurytopic $(\mathrm{Eu}))$ (Aleksandrowicz, 2004; Kosewska, Nietupski \&

145 Ciepielewska, 2007).

146 To determine the significance of differences between the basic parameters describing the

147 biodiversity of the Carabidae assemblages in the analyzed transects and years, the generalized

148 linear model (GLM) was used, which helped to determine the $p$ values using Statistica 13.1

149 software (StatSoft, Inc.). A test of the significance of effects comprised in the model was carried 150 out according to Wald's statistics.

151 Jackknife 2 estimator was used for abundance data (using EstimateS v. 9.1.0 statistical

152 software) and the species accumulation curves, were calculated to access the adequacy of the 153 sampling efficiency (Zahl, 1977; Colwell, 2005).

154 Assessment of the similarity of the Carabidae assemblages in the examined transects and

155 the years of the study was made with the help of a non-metric multidimensional scaling

156 (NMDS), using Morisita's measure of similarity. Assessment of the significance of differences

157 between the analyzed assemblages in the NMDS method was carried out using the ANOSIM

158 non-parametric statistical test (Kenkel \& Orloci, 1986; Clarke, 1993). Impact of environmental

159 variables (year, transect) on the species composition of Carabidae was determined using 
160 redundancy analysis RDA (Ter Braak \& Šmilauer, 1998). This method was chosen based on an

161 analysis of the data distribution, which was linear $(\mathrm{SD}=1.58)$.

162 Each trap was used as a replication for GLM analysis (mean values of abundance, species

163 richness, mean individual biomass MIB) and for species accumulation curves. For NMDS and

164 RDA analysis the data were pooled. Each sample used for statistical analysis consisted of data

165 from all observations in the studied season.

\section{Results}

During the three-year study, 5807 specimens representing 84 species of Carabidae were caught (table 1). Before the small retention program was implemented, 1377 specimens belonging to 52 species were caught. In 2012, the number of species captured at the study site I did not change, although the number of carabid beetles caught ( 927 specimens) decreased. In the final year of the study, the number of species rose to 61, and their abundance increased to 1493 specimens. At study site II, which was a replication, 965 specimens representing 57 species were caught, and the number of carabid individuals caught in 2013 increased to 1 045, while the number of species fell to 43 (table 1). After the implementation of the water retention, the occurrence of new, hygrophilous species (Patrobus atrorufus STRøM, Bembidion mannerheimii C. R. SAHLBERG) and an increase in the share of rare, disappearing or threatened species (Oodes helopioides FABRICIUS, Carabus convexus FABRICIUS, Carabus marginalis FABRICIUS) was

179 observed. Moreover, following the implementation of the water retention program, the presence

180 of a rare species, such as Philorhizus sigma P. ROSSI, was noted (table 1). Despite the rise in the

181 percentage of stenotopic species the hydro-technical works had been completed, the extremely

182 endangered species Epaphius rivularis SCHRANK disappeared (table 1). 
184 mesophilous beetle Pterostichus niger SCHALLER (2009: 22.15\%, 2012 (I): 31.28\%, 2012 (II):

$18532.75 \%, 2013$ (I): 28.80\%, 2013 (II): 32.34\%). In the first year, another numerous species was

186 the forest xerophilous Calathus erratus C.R. SAHLBERG (17.21\%), which was not detected

187 after the water retention project had been implemented. In 2012 and 2013, an increase occurred

188 in the share of hygrophilous species classified as small predators of the spring type of

189 development, they may be eurytopic or they may be associated with open areas (Dyschirius

190 globosus HERBST, Agonum fuliginosum PANZER, Agonum sexpunctatum LINNAEUS) or

191 connected with forests as their habitat (Pterostichus strenuus PANZER, Oxypselaphus obscurus

192 HERBST). In addition, following the water retention, there was a rise in the abundance of

193 peatland hygrophilous beetles (Carabus granulatus LINNAEUS, Oodes helopioides

194 FABRICIUS, Pterostichus diligens STURM, Leistus terminatus PANZER, Patrobus atrorufus

195 STRØM) (table 1).

196 The results obtained from the generalized linear model (GLM) showed a statistically

197 significant impact of the variable factors (transect, year) and their interaction with respect to the

198 presence of epigeic carabid beetles (table 2). The GLM model was chosen because the data had a

199 unimodal distribution. The transects chosen in the study differed from each other in the

200 quantities of individuals and number of species of ground beetles caught (table 3 ).

201 The highest values concerning the number of species and number of individuals prior to

202 the hydro-technical modifications were noted in transect A (peat meadow), while the lowest ones

203 were in transect $\mathrm{C}$ (forest) (figure $2 \mathrm{a}, \mathrm{b}$ ). This is supported by the biological diversity

204 assessment, which additionally demonstrated the most significant contrast during the three-year

205 research between transects $\mathrm{A}(1.25)$ and $\mathrm{C}(0.4)$ (table 3). After the execution of the small water 
206

207

208

209

210

21 212 (figure $2 \mathrm{c}$ ).

213

214

215

216

217

218

219

220

221

222

223

224

225

226

227

228

retention project, there were no quantitative or qualitative dependences confirmed proportional to the distance of the determined transects from the retention reservoirs (figure $2 \mathrm{a}, \mathrm{b}$ ). In 2012, the species richest transect was transect B (forest-meadow ecotone), while the fewest species were caught in transect C (forest). In 2013, the final year of our observations, the above values in individual transects were approximately the same. The MIB analysis showed that the transect localized in a forest habitat (C) was characterized by the highest values in each year of the study

Species accumulation curves for individual transects in the three years of the study confirmed that the sampling effort was adequate (figure 3). Only the rarefaction curve from transect A, located closest to the water reservoirs, in the year of transformation (2012) did not reach an asymptote. This was probably due to unstable conditions leading to fauna migration, which is reflected in the number of singletons (over 50\%).

Graphical and statistical analysis of the interpretation of differences in particular transects was presented with the aid of the non-metric multidimensional scaling (NMDS) analysis. The analysis showed that the Carabidae assemblages inhabiting the analyzed transects, before and after the implementation of the small retention program, were significantly different between one another (ANOSIM; A: $\mathrm{R}=0.30, \mathrm{~B}: \mathrm{R}=0.26, \mathrm{C}: \mathrm{R}=0.32 ; p<0.01$ ). The curves in the graphs illustrating the similarity between the captured Carabidae assemblages in the individual years of entomological observations (Stress $\mathrm{A}=0.22, \mathrm{~B}=0.16, \mathrm{C}=0.14$ ) demonstrated that the statistically most significant difference was in transect A (figure $4 \mathrm{a}, \mathrm{b}, \mathrm{c}$ ).

RDA analysis showing the relationships between ecological groups of ground beetles and environmental variables (year, transect) showed that the first ordination axis, determining $82.4 \%$ of diversity, is positively correlated with the occurrence of large forest zoophages, whose 
229 occurrence determines the growth of MIB. This condition is characteristic of stable habitats,

230 which is typical for forest areas (transect C). An inverse correlation was found for transects A

231 and B. Transect A was correlated with the presence of hygrophilous species associated with peat

232 bogs, while transect B showed a strong correlation with the occurrence of small zoophages

233 belonging to eurytopic and open area species. RDA analysis also showed that the research years

234 were correlated mainly with the second ordination axis, describing almost $10 \%$ of the variation.

235 The highlighted factor - 2009 - is correlated with the occurrence of xerophilic hemizoophages

236 with an autumn type of development. The vector describing 2012 showed an inverse correlation,

237 which indicates large changes in ground beetle assemblages as a result of earth transformations.

238 On the other hand, the vector describing 2013 revealed a tendency corresponding to the state of

239 the carabid assemblages in 2009 , which indicates the tendency of the structure of carabid

240 assemblages to return to the state before implemention of the water retention program (figure 5).

\section{Discussion}

This study, conducted in the Dąbrówka Forest Subdistrict, showed that the number of

244 individuals and species diversity of the captured carabid beetles was at a high level in

245 comparison with results achieved on peatlands in Belarus, Germany and Slovakia

246 (Aleksandrowicz, 2002; Buchholz, Hannig \& Schirmel, 2009; Igondová \& Majzlan, 2015). In

247 our study, we observed over $29 \%$ of all carabid species present in the Masurian Lake District,

248 which may suggest that the analyzed area plays a significant role in the preservation of biological

249 diversity (Aleksandrowicz, Gawroński \& Browarski, 2003; Pacuk \& Regulska, 2014). Similar

250 conclusions can be drawn from analysis the quantitative and qualitative composition of carabid

251 beetle assemblages from peatlands located in the north-east of Poland (Nietupski et al. 2008a; 
252 Nietupski, Ciepielewska \& Kosewska, 2008b; Nietupski et al., 2010; Nietupski, Kosewska \&

253 Lemkowska, 2015). Because of the poor knowledge of entomofauna inhabiting areas subjected

254 to water retention programs, Homburg et al. (2014) suggest that it is necessary to gain more

255 insight into this research question. Our studies conducted in the Olsztyn Forest District have

256 demonstrated that the impact of hydro-technical works directly affect the typical habitat

257 conditions and the composition of caught entomofauna. Kiryluk (2012) and Abell et al. (2019)

258 confirm that when moisture conditions deteriorate, the diversity of flora decreases, which causes

259 impoverishment of fauna. Hence, this is another parameter which directly affects the species

260 composition and the abundance of captured insects, by being a factor that decides about their

261 ability to survive, thereby differentiating the quality of insect assemblages (Thiele, 1977;

262 Nietupski, Kosewska \& Ciepielewska, 2006). Jaworski \& Hilszczański (2013) emphasize that

263 temperature and humidity have both direct and indirect effects on all aspects of the life of both

264 the larvae and imagines of insects.

265 Out of the three years of observations, the entomological material gathered in the first

266 year after the hydro-technical modifications was the least numerous, but this may have been

267 caused by stronger anthropopressure on the analyzed ecosystems. Similar conclusions are drawn

268 by Skłodowski and Mądrzejewska (2008) and by Rosenzweig (1995), who claim that

269 environmental disturbances have a considerable influence, leading to the reduced biodiversity of

270 local ecosystems. Moreover, that year was characterized by relatively high atmospheric

271 precipitation $(700 \mathrm{~mm})$, which could also have had an influence on the presence of carabid

272 beetles (Central Statistical Office in Poland, 2013). In turn, the increase in the diversity of

273 carabids in the last year of the study (2013) may be indicative of the natural conditions slowly

274 normalizing after the implementation of changes in the water relations, whose main goal was to 
275 improve the moisture conditions. These results are in accord with those reported by

276 Jędryczkowski and Kupryjanowicz (2005), who emphasize that species diversity grows

277 proportionally to the increase in the area's moisture content. The effect of soil moisture in forest

278 habitats on beetle assemblages was also demonstrated by Kagawa and Maeto (2014).

280 program in the Dąbrówka Forest Subdistrict also affected the distribution of the carabid beetles

281 in the three research transects. Before the earthworks, the diversity of carabid species decreased

282 directly proportionally to the increasing distance of the set transects from the open area of the

283 peatland meadow (table 3). The earthworks caused certain disturbances in the habitat, associated,

284 inter alia, with increased soil moisture, which caused changes in the spatial structure of carabid

285 assemblages. Fluctuations in the natural environment due to the retention works created stress

286 conditions, which were most distinctly evidenced during the three-year period in transect A.

287 Transect A, located closest to the retention reservoirs, responded the most to the induced

288 changes, which is reflected in the graphical shift of the polygon describing the similarity of the

289 Carabidae assemblages in this transect in the multidimensional spatial scaling approach (NMDS)

290 (figure $4 \mathrm{a}, \mathrm{b}, \mathrm{c}$ ). Following the hydro-technical modifications, the species-richest study site

291 (except study site 2012 II) was transect B (table 3). This transect, by being localized at the edge

292 of two different habitats, could have been conducive to a rise in biodiversity (Yu et al., 2007;

293 Banul, Kosewska \& Borkowski, 2018). Szyszko (2002) states that transitional zones between

294 two different habitats are an excellent foraging site, and subsequently a good place for the

295 development of carabid beetles. Additionally, the above transect in our study was an area

296 subjected to a lesser influence of environmental disturbances, which may also have contributed

297 to higher species diversity. The lowest diversity was noted in the forest zone (transect C) (table 
298 3). Forest habitats are characterized by relatively low diversity, but these assemblages are stable

299 and quite resistant to environmental changes. This opinion has been verified by the observations

300 made in the forest ecosystem located in the Dąbrówka Forest Subdistrict (C) (figure 4 a, b, c).

301 The role of the stable woodland ecosystem in shaping species diversity and abundance of insects

302 has been highlighted by Sushko (2014), who carried out entomological studies in Lithuania.

303 Sushko showed a greater diversity of carabid fauna in a birch forest than in the adjacent peatland.

304 Furthermore, he detected similar species diversity of carabid beetles in a pine forest and on

305 peatland, but determined that the number of beetles in the pine forest was twice as high as on the

306 peatland (Sushko, 2007). Dapkus and Tamutis (2008) reported that the number of species on

307 peatland and in a bordering pine forest was similar, but twice as many carabid specimens were

308 detected in the forest than on the peatland.

309 The adaptability of carabid beetles in the course of evolution led to the emergence of

310 individuals with changeable preferences in regard to habitat, moisture and trophy, or representing

311 different development types (Thiele, 1977). Our analysis, in line with the division adopted for

312 the sake of this research, showed the presence of representatives of all categories of the carabid

313 fauna living in Poland, in terms of their preferred habitat, moisture conditions and trophy. This

314 may be an argument in favor of the internal diversity of the analyzed habitats, and further

315 indicating the high diversity of insects inhabiting this area. The fluctuations that had appeared

316 shaped the structures of biocenoses and the created environmental factors gave rise to new, often

317 valuable populations (Skłodowski \& Zdzioch, 2006). Czyżyk and Porter (2017) undertook a

318 study to assess the influence of small water reservoirs created in woodlands on the surrounding

319 environment. The results they obtained showed the impact of the water bodies on the food base

320 for Carabidae, as a result of which structural changes occurred in carabid assemblages. 
321 Additionally, analysis of transects located at different distances from the water reservoirs

322 revealed the effect of the distance to these study sites on the quantitative and qualitative

323 composition of epigeic carabid beetle assemblages. The differences observed between Carabidae

324 populations in the years of our study, presented via NMDS analysis, only indicate the

325 significance and general direction of changes, which were probably effected by habitat

326 transformations caused by water- and earthworks. A more detailed analysis of changes occurring

327 in carabid assemblages is provided by the RDA redundancy analysis (figure 5). The completed

328 earthworks caused some changes in the habitat, including higher soil moisture. This resulted in a

329 decrease in the share of xerophilic hemizoophages with autumn type of development and an

330 increase in the share of zoophages with higher water requirements, the spring type of

331 development inhabiting forests, open areas and peat bogs, or being eurytopes.

332 The character of changes in the structure of epigeic carabid assemblages induced by the

333 land retention works, in general, should be perceived as positive, in agreement with the

334 expectations of what condition this type of habitat ought to be in (Czyżyk \& Porter, 2017).

335 Zabrocka-Kostrubiec (2008) concludes that measures implemented under the umbrella of small

336 water retention programs play a significant and beneficial role in forest management practice

337 and, in the long term, they assure the permanently sustainable development of woodland

338 ecosystems included in such programs. However, the effects are not unidirectional, because

339 water retention transformations also lead to the disappearance of certain habitats (Bajkowski et

340 al., 2000), and in the case of peatland and marsh habitats, they can result in considerable

341 ecological transformations (Grzywna, 2010). Thus, certain concerns can be raised by the fact that

342 such rapid habitat-related changes may result in the disappearance of rare, stenotopic species,

343 such as E. rivularis in our study. The question of whether this is a permanent outcome, or 
344 whether that species will reappear in the habitat after some time, can be resolved only through

345 further observations.

346

347

\section{Conclusions}

Water as a scarce product is a current problem worldwide. For this reason, programs are being implemented whose main goal is to prevent water shortages. One such program is small water retention. When introducing such changes, however, we must be aware that retention works induce transformations of habitats, and thereby effect changes in the composition of valuable Carabidae fauna. The implementation of this program, on the one hand, causes a decrease in the number of carabid beetles and certain disturbances in the previous structure of their assemblages but, on the other hand, it enables the appearance of Carabidae fauna typical for this type of habitat, with specific habitat and moisture requirements, often valuable in the natural environment. It can, therefore, be concluded that small water retention projects have a strong effect on epigeic fauna, and the transformation mostly involves xerophilous species being replaced by hygrophilous species, with greater ecological adaptability (eurytopic species with the spring type of development). Another demonstrable change is the increase in the number of peat bog carabids, which indicates the direction of habitat-related changes induced by hygrotechnical works. In consequence, the area undergoes transformation and is again settled by hygrophilous organisms, which are otherwise often on the brink of extinction. However, only many further years of research and monitoring of retention areas could give an answer as to whether these processes are short-term and reversible or not. 
366 Acknowledgments: We would like to thank the Olsztyn Forest District for help with material

367 collection.

369 RefERENCES

370 Abell R, Vigerstol K, Higgins J, Kang S, Karres N, Lehner B, Sridhar A, Chapin E. 2019.

371 Freshwater biodiversity conservation through source water protection: Quantifying the potential

372 and addressing the challenges. Aquatic Conservation: Marine and Freshwater Ecosystems. 29, 7,

373 1022-1038 DOI: 10.1002/aqc.3091.

374 Aleksandrowicz OR. 2002. Changes in the carabid fauna of Polesie peat-bog due to drainage,

375 ploughing and agricultural development, in: Szyszko, J. et al., (Eds.). How to protect or what we

376 know about Carabid Beetles. Warsaw Agricultural University Press, Wydawnictwo SGGW

377 Warszawa. pp. 171-184.

378 Aleksandrowicz OR. 2004. Biegaczowate (Carabidae), in: Bogdanowicz, W., Chudzicka, E.,

379 Pilipiuk, I., Skibińska, E., (Eds.). Fauna Polski- charakterystyka i wykaz gatunków. Tom I,

380 Muzeum i Instytut Zoologii PAN, Warszawa. pp. 28-42.

381 Aleksandrowicz O, Gawroński R, Browarski B. 2003. New species of carabid beetles

382 (Coleoptera: Carabidae) from North-East Poland. Baltic Journal of Coleopterology. 3 (2), 153383156.

384 Aleksandrowicz O, Pakula B, Mazur J. 2008. Biegaczowate (Coleoptera: Carabidae) w

385 uprawie pszenicy w okolicy Lęborka. Słupskie Prace Biologiczne. 5, 15-25.

386 Avgin S, Luff ML. 2010. Ground beetles (Coleoptera: Carabidae) as bioindicators of human

387 impact. Munis Entomology \& Zoology. 5, 209-215. 
388 Bajkowski S, Ciepielowski A, Dąbkowski SzL. Fortuński M. 2000. Możliwości zwiększenia

389 retencji wodnej w lasach obrębu Zwoleń w Puszczy Kozienickiej. Prace Instytutu Badawczego

390 Leśnictwa. 4, 905, 29-52.

391 Banul R, Kosewska A, Borkowski J. 2018. Występowanie zwierząt w pofragmentowanym

392 środowisku leśnym - wpływ czynników w skali wyspy i krajobrazu. Leśne Prace Badawcze/

393 Forest Research Papers. 79, 1, 89-100 DOI: 10.2478/frp-2018-0010.

394 Barber HS. 1931. Traps for cave-inhabiting insects. J E. Mitchell Sci Soc. 46, 259-266.

395 Bednarska AJ, Wyżga B, Mikuś P, Kedzior, R. 2018. Ground beetle communities in a

396 mountain river subjected to restoration:The Raba River, Polish Carpathians. Science of the Total

397 Environment. 610-611, 1180-1192 DOI: 10.1016/j.scitotenv.2017.07.161.

398 Blumenfeld S, Lu C, Christophersen T, Coates D. 2010. Water, Wetlands and Forests. A

399 Review of Ecological, Economic and Policy Linkages. Secretariat of the Convention on

400 Biological Diversity and Secretariat of the Ramsar Convention on Wetlands, Montreal and

401 Gland. CBD Technical Series. 47, pp. 39.

402 Buchholz S, Hannig K, Schirmel J. 2009. Ground beetle assemblages of peat bog remnants in

403 Northwest Germany (Coleoptera: Carabidae). Entomologia Generalis. 32, 2, 127-144.

404 Central Statistical Office in Poland. 2010. Ochrona Środowiska. Informacje i opracowania 405 statystyczne. Warszawa. pp. 609.

406 Central Statistical Office in Poland. 2013. Ochrona Środowiska. Informacje i opracowania 407 statystyczne. Warszawa. pp. 580.

408 Central Statistical Office in Poland. 2014. Ochrona Środowiska. Informacje i opracowania 409 statystyczne. Warszawa. pp. 593. 
410 Clarke KR. 1993. Non-parametric multivariate analyses of changes in community structure.

411 Australian Journal of Ecology 18, 1, 117-143 DOI: 10.1111/j.1442-9993.1993.tb00438.x.

412 Colwell RK. 2005. EstimateS: Statistical estimation of species richness and shared species from

413 samples, ver. 9.1.0. http://purl.oclc.org/estimates (accessed 4 June 2020).

414 Czyżyk K, Porter B. 2017. Wpływ małych zbiorników wodnych na wybrane elementy

415 środowiska leśnego. Studia i materiały CEPL w Rogowie. R 19, 51, 2, 131-142.

416 Dapkus D, Tamutis V. 2008. Assemblages of beetles (Coleoptera) in a peatbog and surrounding

417 pine forest. Baltic Journal of Coleopterology. 8, 1, 31-40.

418 European Environment Agency. 2015. Water-retention potential of Europe's forests, EEA

419 Technical report 13/2015. European Environment Agency, Copenhagen, Denmark. pp. 46.

420 Forest Data Bank. 2019. Available athttp:/www.bdl.lasy.gov.pl/portal/ (accessed 3 October

421 2019).

422 Gerlach J, Samways M, Pryke J. 2013. Terrestrial invertebrates as bioindicators: an

423 overviewof available taxonomic groups. Journal of Insect Conservation. 17, 831-850 DOI:

424 10.1007/s10841-013-9565-9.

425 Grzywna A. 2010. Zmienność warunków wodnych gleby murszowo-torfowej MtIbb w

426 warunkach melioracji odwodniającej. Acta Scientiarum Polonorum. 9, 1-2, 29-36.

427 Gustafsson L, Baker SC, Bauhus J, Beese WJ, Brodie A, Kouki J, Lindenmayer DB,

428 Lõhmus A, Pastur GM, Messier Ch, Neyland M, Palik B, Sverdrup-Thygeson A, Volney

429 WJA, Wayne A, Franklin JF. 2012. Retention forestry to maintain multifunctional forests: A

430 world perspektive. BioScience. 62, 633-645 DOI: 10.1525/bio.2012.62.7.6.

431 Hansson LA, Brönmark C, Nilsson PA, Äbjörnsson K. 2005. Conflicting demands on wetland

432 ecosystem services:nutrient retention, biodiversity or both? Freshwater Biology. 50, 705-714

433 DOI: $10.1111 / \mathrm{j} .1365-2427.2005 .01352 . x$. 
434 Homburg K, Homburg N, Schäfer F, Schuldt A. 2014. Carabids.org - a dynamic online

435 database of ground beetle species traits (Coleoptera, Carabidae). Insect Conservation and 436 Diversity. 7, 3, 195-205 DOI: 10.1111/icad.12045.

437 Igondová E, Majzlan O. 2015. Assemblages of ground beetles (Carabidae, Coleoptera) in 438 peatland habitat, surrounding dry pine forests and meadows. Folia Oecologica. 42, 11, 21-28.

439 Janusz E, Jędryka S, Kopeć D, Miler AT. 2011. Woda dla lasu- las dla wody, na przykładzie 440 Nadleśnictwa Kolumna. Infrastruktura I Ekologia Terenów Wiejskich. Polska Akademia Nauk. $441 \quad 1,275-288$.

442 Jaworski T, Hilszczański J. 2013. Wpływ zmian temperatury i wilgotności na cykle rozwojowe 443 i znaczenie owadów w ekosystemach leśnych w związku z prawdopodobnymi zmianami 444 klimatycznymi. Leśne Prace Badawcze. 74, 4, 345-355 DOI: 10.2478/frp-2013-0033.

445 Jędryczkowski WB, Kupryjanowicz J. 2005. Biegaczowate, Carabidae (chrząszcze,

446 Coleoptera) czterech środowisk Biebrzańskiego Parku Narodowego. Przyroda Biebrzańskiego

447 Parku Narodowego. Biebrzański Park Narodowy. Osowiec-Twierdza. 331-335.

448 Kagawa Y, Maeto K. 2014. Ground beetle (Coleoptera: Carabidae) assemblages associated with 449 a satoyama landscape in Japan: The effects of soil moisture, weed height, and distance from 450 woodlands. Applied Entomology and Zoology. 49, 3, 429-436 DOI: 10.1007/s13355-014-0266$451 \mathrm{y}$.

452 Kenkel NC, Orloci L. 1986. Applying Metric and Nonmetric Multidimensional Scaling to 453 Ecological Studies: Some New Results. Ecology. 67, 919-928 DOI: 10.2307/1939814.

454 Kędziora A, Kępińska-Kasprzak M, Kowalczyk P, Kundzewicz ZW, Miler AT, Pierzgalski 455 E, Tokarczyk T. 2014. Zagrożenia związane z niedoborem wody. Nauka 1. 149-172. 
456 Kiryluk A. 2012. Ocena uwilgotnienia siedlisk metodą fitoindykacji na zmeliorowanym

457 łąkowym obiekcie pobagiennym Supraśl Górna. Inżyniernia Ekologiczna. 29, 66-75.

458 Koivula M. 2011. Useful model organisms, indicators, or both? Ground beetles (Coleoptera,

459 Carabidae) reflecting environmental conditions. ZooKeys. 100, 287-317 DOI:

$460 \quad$ 10.3897/zookeys.100.1533.

461 Koralay N, Kara O. 2018. Forestry activities and surface water quality in a watershed.

462 European Journal of Forest Engineering. 4. 2. 70-82.

463 Kosewska A, Nietupski M, Ciepielewska D. 2007. Zgrupowania biegaczowatych (Coleoptera:

464 Carabidae) zadrzewień śródpolnych i pól z Tomaszkowa koło Olsztyna. Wiadomości

465 entomologiczne. Poznań. 26, 3, 153-168.

466 Kosewska A, Nietupski M. 2015. Field and forest water bodies as landscape elements affecting 467 the biodiversity of carabid beetles (Col.; Carabidae). Polish Journal of Natural Sciences. 30, 4, $468 \quad 367-378$.

469 Kotze DJ, Brandmayr P, Casale A, Dauffy RE, Dekoninck W, Koivula MJ, Lövei GL, 470 Mossakowski D, Noordijk J, Paarmann W, Pizzolotto R, Saska P, Schwerk A, Serrano J, 471 Szyszko J, Taboada A, Turin H, Venn S, Vermeulen R, Zetto T. 2011. Forty years of carabid

472 beetle research in Europe - from taxonomy, biology, ecology and population studies to

473 bioindication, habitat assessment and conservation. ZooKeys. 100, 55-148. DOI:

474 10.3897/zookeys.100.1523.

475 Larsson SG. 1939. Entwicklungstypen und Entwicklungszeiten der dänischen Carabiden.

476 Entomologiske Meddelelser. 20. pp. 559.

477 Leśniak A. 1985. Organizacja a stabilność zgrupowania na przykładzie Carabidae. Polskie

478 Towarzystwo Gleboznawcze. Warszawa. 1-8. 
479 Liberacki D, Szafrański Cz. 2013. Tendencje zmian położenia zwierciadła wody gruntowej w 480 wybranych zlewniach na obszarze Puszczy Zielonka. Rocznik Ochrony Środowiska. 15, 24254812436.

482 Mc Geoch MA. 1998. The selection, testing and application of terrestrial insects as 483 bioindicators. Biological Reviews. 73, 2, 81-201. DOI: 10.1111/j.1469-185X.1997.tb00029.x. 484 Miler AT, Czerniak A, Grajewski S, Kamiński B, Krysztofiak- Kaniewska A, Okoński B. 485 2013. Zagrożenia stabilności stosunków wodnych w leśnych ombrogenicznych mokradłach. 486 Infrastruktura i Ekologia Terenów Wiejskich. 3/IV, 31-44.

487 Mioduszewski W. 2010. Rola mokradeł w gospodarce wodnej. Wiadomości Melioracyjne i 488 Łąkarskie. 53, 1, 11-14.

489 Nietupski M, Kosewska A, Ciepielewska D. 2006. Porównanie zgrupowań Carabidae 490 (Coleoptera) rezerwatu torfowiskowego „Redykajny” i zadrzewienia śródmiejskiego Olsztyna. 491 Wiadomości Entomologiczne. 25. Supl. 1, 61-70.

492 Nietupski M, Kosewska A, Ciepielewska D. 2007. Zgrupowania epigeicznych biegaczowatych 493 (Coleoptera: Carabidae) dwóch śródleśnych łąk kośnych o różnym stopniu uwilgotnienia, w 494 okolicach Olsztyna. Wiadomości entomologiczne. 26, 3, 185-193.

495 Nietupski M, Kosewska A, Ciepielewska D, Sądej W. 2008a. Zgrupowania Carabidae leśnego 496 rezerwatu torfowiskowego zlokalizowanego w obrębie aglomeracji miejskiej. Sylwan. 11, 16-25. 497 Nietupski M, Ciepielewska D, Kosewska A. 2008b. Assemblages of epigeic Carabidae (Col.) 498 in a peatbog nature reserve situated in an urban area. Polish Journal of Natural Sciences. 23, 3, 499 611-623. 
500 Nietupski M, Sowiński P, Sądej W, Kosewska A. 2010. Content of organic C and pH of bog

501 and post-bog soils versus the presence of ground beetles Carabidae in Stary Dwór near Olsztyn.

502 Journal of Elementology. 15, 3, $581-591$.

503 Nietupski M, Kosewska A, Lemkowska B. 2015. Grasslands areas on carbonate gyttia soils in 504 the Olsztyn Lake District as specific habitats for ground beetles (Col.: Carabidae). Baltic Journal 505 of Coleopterology. 15, 1, 57-70.

506 Pacuk B, Regulska E. 2014. Nowe stanowiska interesujących gatunków biegaczowatych

507 (Coleoptera: Carabidae) na Pojezierzu Mazurskim. Wiadomości Entomologiczne. Poznań. 33, 508 3, 165-181.

509 Pawłowski J, Kubisz D, Mazur M. 2002. Coleoptera - Chrząszcze, in: Głowacki Z. (Eds.)

510 Czerwona lista zwierząt ginących i zagrożonych w Polsce. Instytut Ochrony Przyrody PAN.

511 Kraków. 88-110.

512 Pierzgalski E. 2008. Relacje między lasem a wodą- przegląd problemów. Studia i Materiały

513 Centrum Edukacji Przyrodniczo- Leśnej. 2 (18). 13-23.

514 Rainio J, Niemelä J. 2003. Ground beetles (Coleoptera: Carabidae) as bioindicators.

515 Biodiversity and Conservation. 12, 487-506 DOI: 10.1023/A:1022412617568.

516 Rosenzweig ML. 1995. Species diversity in space and time. Cambridge University Press.

517 Cambridge. pp. 439 DOI: 10.1017/CBO9780511623387.

518 Rulik M, White SM. 2019. The role of water in the landscape. Assessment and Protection of

519 Water Resources in the Czech Republic, Springer. pp. 71-90.

520 Shannon CE, Weaver W. 1949. The mathematicaltheory of communication. University of

521 Illinois Press, Urban. pp. 144. 
522 Skłodowski J, Zdzioch P. 2006. Biegaczowate (Coleoptera: Carabidae) w drugim roku

523 spontanicznej sukcesji regeneracyjnej zniszczonych przez huragan drzewostanów Puszczy

524 Piskiej. Wiadomości Entomologiczne. 25, 97-110.

525 Skłodowski J, Mądrzejewska K. 2008. Zgrupowania biegaczowatych jako zooindykator presji

526 turystyki żeglarskiej w ekotonach leśno- jeziornych. Sylwan. 8, 35-46.

527 Sushko G. 2007. Beetles (Coleoptera) of Raised Bogs in North-Western Belarus (Belarusian

528 Land O'Lakes). Baltic Journal of Coleopterology. 7, 2, 207-214.

529 Sushko G. 2014. Spatial distribution of epigeic beetles (Insecta, Coleoptera) in the „Yelnia” peat

530 bog. Baltic Journal of Coleopterology. 14, 2, 151-161.

531 Szyszko J. 2002. Możliwości wykorzystania biegaczowatych (Carabidae, Coleoptera) do oceny

532 zaawansowania procesów sukcesyjnych w środowisku leśnym-aspekty gospodarcze. Sylwan.

$53312,45-59$.

534 Szyszko J, Vermeulen H, Klimaszewski K, Abs M, Schwerk A. 2000. Mean Individual

535 Biomass (MIB) of Carabidae as an indicator of the state of the environment, in: Brandamayr. P.,

536 Lovei G., Casale A., Vigna Taglianti A. [Eds.]. Natural History and Appliesd Ecology of

537 Carabid Beetles. 289-294.

538 Ter Braak, CJF, Šmilauer P. 1998. CANOCO Reference Manual and User’s Guide to Canoco

539 for Windows. Microcomputer Power, Ithaca, USA.

540 Thiele. 1977. Carabid beetles in their environments. Springer- Verlag, Berlin- Heidelberg-New

$541 \quad$ York. 329.

542 Tőzsér D, Magura T, Simon E, Mizser S, Papp D, Tóthmérész B. 2019. Pollution intensity-

543 dependent metal accumulation in ground beetles: a meta-analysis. Environmental Science and

544 Pollution Research. 26, 32092-32102 DOI: 10.1007/s11356-019-06294-5. 
545 www.sporol.warmia.mazury.pl/files/0/4229/Mala_retencja.pdf. (accessed 5 October 2018).

546 www.olsztyn.olsztyn.lasy.gov.pl (accessed 3 October 2019).

547 www.google.pl/maps (accessed 18 October 2019).

548 Yu XD, Luo TH, Zhou HZ, Yang J. 2007. Distribution of Carabid Beetles (Coleoptera:

549 Carabidae) Across a Forest-Grassland Ecotone in Southwestern China. Environmental

550 Entomology. 36 (2) DOI: 10.1603/0046-225X(2007)36[348:DOCBCC]2.0.CO;2.

551 Zabrocka-Kostrubiec U. 2008. Mała retencja w Lasach Państwowych- stan i perspektywy.

552 Studia i Materiały Centrum Edukacji Przyrodniczo- Leśnej. 2, 18, 55-63.

553 


\section{Table $\mathbf{1}$ (on next page)}

Species composition, number of individuals, and structure of dominance in the Carabidae assemblages dwelling in the analyzed study sites located in the Dąbrówka Forest 
Tab. 1

\begin{tabular}{|c|c|c|c|c|c|c|c|c|c|c|c|}
\hline \multirow{3}{*}{ study site } & \multirow[b]{3}{*}{$\begin{array}{c}\text { ecological } \\
\text { description }\end{array}$} & \multirow{2}{*}{\multicolumn{2}{|c|}{$\begin{array}{c}2009 \\
\text { I }\end{array}$}} & \multicolumn{4}{|c|}{2012} & \multicolumn{4}{|c|}{2013} \\
\hline & & & & \multicolumn{2}{|c|}{$\mathbf{I}$} & \multicolumn{2}{|c|}{ II } & \multicolumn{2}{|c|}{$\mathbf{I}$} & \multicolumn{2}{|c|}{ II } \\
\hline & & number & $\begin{array}{c}\text { dominance } \\
(\%)\end{array}$ & number & $\begin{array}{c}\text { dominance } \\
\text { (\%) }\end{array}$ & number & $\begin{array}{c}\text { dominance } \\
(\%)\end{array}$ & number & $\begin{array}{c}\text { dominance } \\
(\%)\end{array}$ & number & $\begin{array}{c}\text { dominance } \\
(\%)\end{array}$ \\
\hline Pterostichus niger (SCHALLER, 1783) & $\mathrm{F}, \mathrm{M}, \mathrm{Lz}, \mathrm{Ab}$ & 305 & 22,15 & 290 & 31,28 & 316 & 32,75 & 430 & 28,80 & 338 & 32,34 \\
\hline Calathus erratus (C.R. SAHLBERG, 1827) & $\mathrm{F}, \mathrm{Xe}, \mathrm{Sz}, \mathrm{Ab}$ & 237 & 17,21 & 0 & 0,00 & 0 & 0,00 & 0 & 0,00 & 0 & 0,00 \\
\hline Harpalus tardus (PANZER, 1796) & $\mathrm{Oa}, \mathrm{Xe}, \mathrm{Hz}, \mathrm{Sb}$ & 78 & 5,66 & 16 & 1,73 & 20 & 2,07 & 22 & 1,47 & 7 & 0,67 \\
\hline Poecilus versicolor (STURM, 1824) & $\mathrm{Oa}, \mathrm{M}, \mathrm{Sz}, \mathrm{Sb}$ & 96 & 6,97 & 39 & 4,21 & 52 & 5,39 & 50 & 3,35 & 41 & 3,92 \\
\hline Carabus marginalis FABRICIUS, 1794 & $\mathrm{~F}, \mathrm{M}, \mathrm{Lz}, \mathrm{Sb}$ & 63 & 4,58 & 69 & 7,44 & 16 & 1,66 & 83 & 5,56 & 22 & 2,11 \\
\hline Dyschirius globosus (HERBST, 1784) & $\mathrm{Oa}, \mathrm{H}, \mathrm{Sz}, \mathrm{Sb}$ & 84 & 6,10 & 128 & 13,81 & 115 & 11,92 & 97 & 6,50 & 56 & 5,36 \\
\hline Harpalus rufipes (DE GEER, 1774) & $\mathrm{Oa}, \mathrm{M}, \mathrm{Hz}, \mathrm{Ab}$ & 28 & 2,03 & 7 & 0,76 & 2 & 0,21 & 7 & 0,47 & 1 & 0,10 \\
\hline Epaphius secalis (PAYKULL, 1790) & $\mathrm{Oa}, \mathrm{M}, \mathrm{Hz}, \mathrm{Ab}$ & 125 & 9,08 & 24 & 2,59 & 17 & 1,76 & 109 & 7,30 & 51 & 4,88 \\
\hline Amara aenea (DE GEER, 1774) & $\mathrm{Oa}, \mathrm{Xe}, \mathrm{Hz}, \mathrm{Sb}$ & 7 & 0,51 & 2 & 0,22 & 1 & 0,10 & 2 & 0,13 & 0 & 0,00 \\
\hline Harpalus rubripes (DUFTSCHMID, 1812) & $\mathrm{Oa}, \mathrm{Xe}, \mathrm{Hz}, \mathrm{Sb}$ & 5 & 0,36 & 4 & 0,43 & 1 & 0,10 & 3 & 0,20 & 2 & 0,19 \\
\hline Amara lunicollis SCHIØDTE, 1837 & $\mathrm{Oa}, \mathrm{M}, \mathrm{Hz}, \mathrm{Ab}$ & 26 & 1,89 & 5 & 0,54 & 7 & 0,73 & 10 & 0,67 & 5 & 0,48 \\
\hline Amara communis (PANZER, 1797) & $\mathrm{Oa}, \mathrm{M}, \mathrm{Hz}, \mathrm{Sb}$ & 18 & 1,31 & 12 & 1,29 & 15 & 1,55 & 40 & 2,68 & 16 & 1,53 \\
\hline Bembidion gilvipes (STURM, 1825) & $\mathrm{Oa}, \mathrm{H}, \mathrm{Sz}, \mathrm{Sb}$ & 78 & 5,66 & 39 & 4,21 & 74 & 7,67 & 51 & 3,42 & 32 & 3,06 \\
\hline Amara convexior STEPHENS, 1828 & $\mathrm{Oa}, \mathrm{M}, \mathrm{Hz}, \mathrm{Sb}$ & 2 & 0,15 & 6 & 0,65 & 6 & 0,62 & 24 & 1,61 & 15 & 1,44 \\
\hline Poecilus lepidus (LESKE, 1785) & $\mathrm{Oa}, \mathrm{Xe}, \mathrm{Sz}, \mathrm{Sb}$ & 10 & 0,73 & 3 & 0,32 & 0 & 0,00 & 4 & 0,27 & 0 & 0,00 \\
\hline Amara bifrons (GYLLENHAL, 1810) & $\mathrm{Oa}, \mathrm{Xe}, \mathrm{Hz}, \mathrm{Ab}$ & 14 & 1,02 & 0 & 0,00 & 0 & 0,00 & 1 & 0,07 & 0 & 0,00 \\
\hline Pterostichus diligens (STURM, 1824) & $\mathrm{Pb}, \mathrm{H}, \mathrm{Sz}, \mathrm{Sb}$ & 34 & 2,47 & 40 & 4,31 & 19 & 1,97 & 53 & 3,55 & 40 & 3,83 \\
\hline Agonum fuliginosum (PANZER, 1809) & $\mathrm{Eu}, \mathrm{H}, \mathrm{Sz}, \mathrm{Sb}$ & 32 & 2,32 & 61 & 6,58 & 28 & 2,90 & 112 & 7,50 & 63 & 6,03 \\
\hline
\end{tabular}


Pterostichus strenuus (PANZER, 1796)

Calathus melanocephalus (LINNAEUS, 1758)

Harpalus latus (LINNAEUS, 1758)

Clivina fossor (LINNAEUS, 1758)

Carabus nemoralis O.F. MÜLLER, 1764

Harpalus smaragdinus (DUFTSCHMID, 1812)

Amara spreta DEJEAN, 1831

Bradycellus harpalinus (AUDINET-SERVILLE,

1821)

Syntomus truncatellus (LINNE, 1761)

Synuchus vivalis (ILLIGER, 1798)

Carabus hortensis LINNAEUS, 1758

Harpalus affinis (SCHRANK, 1781)

Epaphius rivularis (SCHRANK, 1781)

Amara tibialis (PAYKULL, 1798)

Bradycellus csikii LACZO, 1912

Leistus terminatus PANZER, 1793

Loricera pilicornis (FABRICIUS, 1775)

Poecilus cupreus (LINNAEUS, 1758)

Pterostichus vernalis (PANZER, 1796)

Amara curta DEJEAN, 1828

\begin{tabular}{lcl} 
F, H, Sz, Sb & 14 & 1,02 \\
$\mathrm{Oa}, \mathrm{M}, \mathrm{Sz}, \mathrm{Ab}$ & 5 & 0,36 \\
$\mathrm{Eu}, \mathrm{M}, \mathrm{Hz}, \mathrm{Ab}$ & 7 & 0,51 \\
$\mathrm{Oa}, \mathrm{M}, \mathrm{Sz}, \mathrm{Sb}$ & 15 & 1,09 \\
$\mathrm{Oa}, \mathrm{M}, \mathrm{Sz}, \mathrm{Sb}$ & 7 & 0,51 \\
$\mathrm{Oa}, \mathrm{Xe}, \mathrm{Hz}, \mathrm{Sb}$ & 1 & 0,07 \\
$\mathrm{Oa}, \mathrm{Xe}, \mathrm{Hz}, \mathrm{Sb}$ & 0 & 0,00 \\
$\mathrm{Oa}, \mathrm{Xe}, \mathrm{Hz}, \mathrm{Sb}$ & 0 & 0,00 \\
$\mathrm{Oa}, \mathrm{Xe}, \mathrm{Sz}, \mathrm{Sb}$ & 6 & 0,44 \\
$\mathrm{Oa}, \mathrm{Xe}, \mathrm{Sz}, \mathrm{Ab}$ & 5 & 0,36 \\
$\mathrm{~F}, \mathrm{M}, \mathrm{Lz}, \mathrm{Ab}$ & 10 & 0,73 \\
$\mathrm{Eu}, \mathrm{Xe}, \mathrm{Hz}, \mathrm{Sb}$ & 4 & 0,29 \\
$\mathrm{~Pb}, \mathrm{H}, \mathrm{Sz}, \mathrm{Ab}$ & 15 & 1,09 \\
$\mathrm{Oa}, \mathrm{Xe}, \mathrm{Hz}, \mathrm{Sb}$ & 0 & 0,00 \\
$\mathrm{Oa}, \mathrm{M}, \mathrm{Hz}, \mathrm{Sb}$ & 0 & 0,00 \\
$\mathrm{~Pb}, \mathrm{H}, \mathrm{Sz}, \mathrm{Ab}$ & 1 & 0,07 \\
$\mathrm{~Pb}, \mathrm{H}, \mathrm{Sz}, \mathrm{Sb}$ & 1 & 0,07 \\
$\mathrm{Oa}, \mathrm{M}, \mathrm{Sz}, \mathrm{Sb}$ & 1 & 0,07 \\
$\mathrm{Oa}, \mathrm{M}, \mathrm{Sz}, \mathrm{Sb}$ & 4 & 0,29 \\
$\mathrm{Oa}, \mathrm{Xe}, \mathrm{Hz}, \mathrm{Sb}$ & 6 & 0,44 \\
$\mathrm{Eu}, \mathrm{H}, \mathrm{Sz}, \mathrm{Sb}$ & 0 & 0,00 \\
$\mathrm{~Pb}, \mathrm{H}, \mathrm{Sz}, \mathrm{Ab}$ & 0 & 0,00 \\
$\mathrm{~F}, \mathrm{M}, \mathrm{Hz}, \mathrm{Ab}$ & 1 & 0,07 \\
$\mathrm{Oa}, \mathrm{M}, \mathrm{Sz}, \mathrm{Ab}$ & 1 & 0,07 \\
$\mathrm{~F}, \mathrm{Xe}, \mathrm{Lz}, \mathrm{Sb}$ & 0 & 0,00 \\
& & \\
\hline
\end{tabular}

\begin{tabular}{|c|c|}
\hline 0,76 & 11 \\
\hline 0,11 & 2 \\
\hline 0,22 & 6 \\
\hline 1,29 & 8 \\
\hline 1,51 & 24 \\
\hline 0,00 & 0 \\
\hline 0,11 & 0 \\
\hline 0,11 & 0 \\
\hline 0,11 & 3 \\
\hline 0,00 & 2 \\
\hline 2,16 & 40 \\
\hline 0,00 & 1 \\
\hline 0,00 & 0 \\
\hline 0,11 & 0 \\
\hline 0,00 & 0 \\
\hline 0,97 & 10 \\
\hline 0,00 & 0 \\
\hline 0,00 & 0 \\
\hline 0,32 & 3 \\
\hline 1,40 & 8 \\
\hline 0,00 & 2 \\
\hline 0,00 & 2 \\
\hline 0,00 & 0 \\
\hline 0,00 & 0 \\
\hline 0,76 & 3 \\
\hline
\end{tabular}

\begin{tabular}{|c|c|}
\hline 1,14 & 39 \\
\hline 0,21 & 1 \\
\hline 0,62 & 5 \\
\hline 0,83 & 5 \\
\hline 2,49 & 9 \\
\hline 0,00 & 0 \\
\hline 0,00 & 0 \\
\hline 0,00 & 5 \\
\hline 0,31 & 3 \\
\hline 0,21 & 3 \\
\hline 4,15 & 43 \\
\hline 0,10 & 0 \\
\hline 0,00 & 0 \\
\hline 0,00 & 3 \\
\hline 0,00 & 1 \\
\hline 1,04 & 21 \\
\hline 0,00 & 2 \\
\hline 0,00 & 0 \\
\hline 0,31 & 4 \\
\hline 0,83 & 10 \\
\hline 0,21 & 4 \\
\hline 0,21 & 6 \\
\hline 0,00 & 1 \\
\hline 0,00 & 0 \\
\hline 0,31 & 16 \\
\hline
\end{tabular}

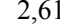

2,68

0,07

$$
0,33
$$

Bembidion mannerheimii (C. R. SAHLBERG, 1827$)$

Patrobus atrorufus (STRØM, 1768)

Amara brunnea (GYLLENHAL, 1810)

Calathus fuscipes GOEZE, 1777

Carabus convexus FABRICIUS, 1775 
Harpalus griseus (PANZER, 1796)

Microlestes minutulus (GOEZE, 1777)

Oxypselaphus obscurus (HERBST, 1784)

Amara equestris (DUFTSCHMID, 1812)

Amara familiaris (DUFTSCHMID, 1812)

Bembidion guttula (FABRICIUS, 1792)

Carabus granulatus LINNAEUS, 1758

Pterostichus minor (GYLLENHAL, 1827)

Acupalpus exiguus DEJEAN, 1829

Amara similata (GYLLENHAL, 1810)

Calathus ambiguus (PAYKULL, 1790)

Carabus cancellatus ILLIGER, 1798

Carabus glabratus PAYKULL, 1790

Harpalus luteicornis (DUFTSCHMID, 1812)

Leistus ferrugineus LINNAEUS, 1758

Notiophilus palustris (DUFTSCHMID, 1812)

Oodes helopioides (FABRICIUS, 1792)

Pterostichus nigrita (PAYKULL, 1790)

$\mathrm{Oa}, \mathrm{Xe}, \mathrm{Hz}, \mathrm{Ab}$

$\mathrm{F}, \mathrm{H}, \mathrm{Sz}, \mathrm{Sb}$

$\mathrm{Oa}, \mathrm{Xe}, \mathrm{Hz}, \mathrm{Ab}$

$\mathrm{Eu}, \mathrm{M}, \mathrm{Hz}, \mathrm{Sb}$

$\mathrm{Oa}, \mathrm{H}, \mathrm{Sz}, \mathrm{Sb}$

$\mathrm{Pb}, \mathrm{H}, \mathrm{Lz}, \mathrm{Sb}$

$\mathrm{Pb}, \mathrm{H}, \mathrm{Sz}, \mathrm{Sb}$

$\mathrm{Pb}, \mathrm{H}, \mathrm{Hz}, \mathrm{Sb}$

$\mathrm{Oa}, \mathrm{M}, \mathrm{Hz}, \mathrm{Sb}$

$\mathrm{Oa}, \mathrm{Xe}, \mathrm{Sz}, \mathrm{Ab}$

$\mathrm{Oa}, \mathrm{Xe}, \mathrm{Sz}, \mathrm{Ab}$

F, M, Lz, Ab

$\mathrm{Oa}, \mathrm{M}, \mathrm{Hz}, \mathrm{Sb}$

F, M, Sz, Ab

$\mathrm{Oa}, \mathrm{M}, \mathrm{Sz}, \mathrm{Sb}$

$\mathrm{Pb}, \mathrm{H}, \mathrm{Sz}, \mathrm{Sb}$

F, H, Sz, Sb

Pterostichus oblongopunctatus (FABRICIUS, 1787)

Stenolophus mixtus (HERBST, 1784)

$\mathrm{F}, \mathrm{M}, \mathrm{Sz}, \mathrm{Sb}$

$\mathrm{Oa}, \mathrm{H}, \mathrm{Sz}, \mathrm{Sb}$

$\mathrm{Oa}, \mathrm{H}, \mathrm{Sz}, \mathrm{Sb}$

$\mathrm{Pb}, \mathrm{H}, \mathrm{Sz}, \mathrm{Sb}$

$\mathrm{Oa}, \mathrm{H}, \mathrm{Hz}, \mathrm{Sb}$

$\mathrm{Oa}, \mathrm{H}, \mathrm{Hz}, \mathrm{Sb}$

$\mathrm{F}, \mathrm{M}, \mathrm{Sz}, \mathrm{Sb}$

$\mathrm{F}, \mathrm{M}, \mathrm{Sz}, \mathrm{Sb}$

$\begin{array}{ll}0,00 & 0 \\ 0,00 & 1 \\ 0,07 & 4 \\ 0,07 & 0 \\ 0,07 & 0 \\ 0,00 & 0 \\ 0,22 & 18 \\ 0,29 & 3 \\ 0,07 & 1 \\ 0,07 & 3 \\ 0,07 & 0 \\ 0,00 & 2 \\ 0,00 & 2 \\ 0,51 & 0 \\ 0,07 & 0 \\ 0,07 & 1 \\ 0,22 & 19 \\ 0,07 & 1 \\ 0,00 & 17 \\ 0,00 & 0 \\ 0,07 & 3 \\ 0,00 & 0 \\ 0,00 & 0 \\ 0,15 & 00 \\ 0\end{array}$

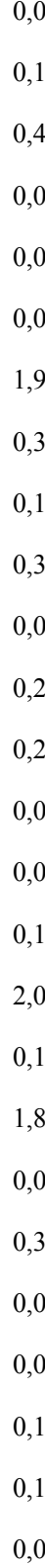

\section{0,00}

, 11 43

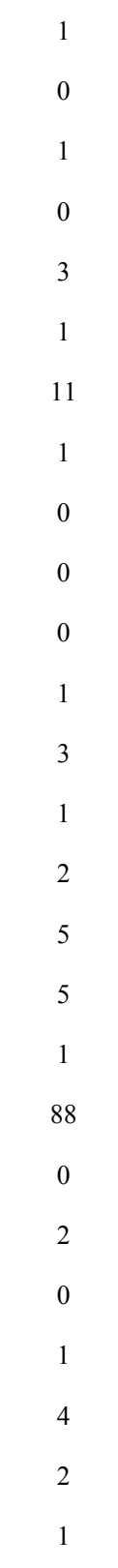

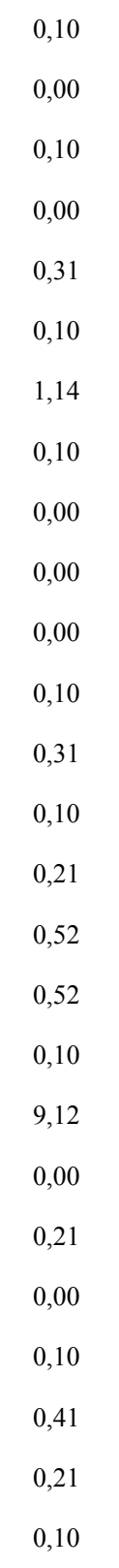

0
0
4
2
0
1
37
16

\section{0,00}




\begin{tabular}{|c|c|c|c|c|c|c|c|c|c|c|c|}
\hline Badister sodalis (DUFTSCHMID, 1812) & $\mathrm{Pb}, \mathrm{H}, \mathrm{Sz}, \mathrm{Sb}$ & 0 & 0,00 & 1 & 0,11 & 0 & 0,00 & 2 & 0,13 & 0 & 0,00 \\
\hline Bembidion doris (PANZER, 1796) & $\mathrm{Pb}, \mathrm{H}, \mathrm{Sz}, \mathrm{Sb}$ & 0 & 0,00 & 0 & 0,00 & 0 & 0,00 & 1 & 0,07 & 0 & 0,00 \\
\hline Metallina properans (STEPHENS, 1828) & $\mathrm{Oa}, \mathrm{M}, \mathrm{Sz}, \mathrm{Sb}$ & 0 & 0,00 & 1 & 0,11 & 1 & 0,10 & 0 & 0,00 & 0 & 0,00 \\
\hline Bembidion quadrimaculatum (LINNAEUS, 1760) & $\mathrm{Oa}, \mathrm{M}, \mathrm{Sz}, \mathrm{Sb}$ & 0 & 0,00 & 0 & 0,00 & 0 & 0,00 & 1 & 0,07 & 0 & 0,00 \\
\hline Calathus micropterus (DUFTSCHMID, 1812) & $\mathrm{F}, \mathrm{M}, \mathrm{Sz}, \mathrm{Ab}$ & 2 & 0,15 & 5 & 0,54 & 10 & 1,04 & 10 & 0,67 & 17 & 1,63 \\
\hline Carabus arvensis HERBST, 1784 & $\mathrm{~F}, \mathrm{Xe}, \mathrm{Lz}, \mathrm{Sb}$ & 0 & 0,00 & 2 & 0,22 & 1 & 0,10 & 2 & 0,13 & 1 & 0,10 \\
\hline Chlaenius nigricornis (FABRICIUS, 1787) & $\mathrm{Oa}, \mathrm{H}, \mathrm{Sz}, \mathrm{Sb}$ & 0 & 0,00 & 1 & 0,11 & 1 & 0,10 & 0 & 0,00 & 0 & 0,00 \\
\hline Cicindela hybrida LINNAEUS, 1758 & $\mathrm{Oa}, \mathrm{Xe}, \mathrm{Lz}, \mathrm{Sb}$ & 0 & 0,00 & 0 & 0,00 & 0 & 0,00 & 1 & 0,07 & 0 & 0,00 \\
\hline Harpalus laevipes ZETTERSTEDT 1828 & $\mathrm{~F}, \mathrm{M}, \mathrm{Hz}, \mathrm{Sb}$ & 0 & 0,00 & 0 & 0,00 & 1 & 0,10 & 1 & 0,07 & 1 & 0,10 \\
\hline Lebia chlorocephala (J. J. HOFFMANN, 1803) & $\mathrm{Oa}, \mathrm{M}, \mathrm{Sz}, \mathrm{Sb}$ & 0 & 0,00 & 2 & 0,22 & 0 & 0,00 & 0 & 0,00 & 0 & 0,00 \\
\hline Limodromus assimilis PAYKULL, 1790 & $\mathrm{~F}, \mathrm{H}, \mathrm{Sz}, \mathrm{Sb}$ & 0 & 0,00 & 1 & 0,11 & 0 & 0,00 & 0 & 0,00 & 0 & 0,00 \\
\hline Nebria brevicollis (FABRICIUS, 1792) & $\mathrm{Eu}, \mathrm{M}, \mathrm{Sz}, \mathrm{Ab}$ & 0 & 0,00 & 0 & 0,00 & 0 & 0,00 & 0 & 0,00 & 1 & 0,10 \\
\hline Notiophilus biguttatus (FABRICIUS, 1779) & $\mathrm{F}, \mathrm{M}, \mathrm{Sz}, \mathrm{Sb}$ & 0 & 0,00 & 0 & 0,00 & 1 & 0,10 & 0 & 0,00 & 0 & 0,00 \\
\hline Philorhizus sigma (P. ROSSI, 1790) & $\mathrm{Oa}, \mathrm{Xe}, \mathrm{Sz}, \mathrm{Sb}$ & 0 & 0,00 & 0 & 0,00 & 1 & 0,10 & 0 & 0,00 & 0 & 0,00 \\
\hline Pterostichus anthracinus (ILLIGER, 1798) & $\mathrm{Pb}, \mathrm{H}, \mathrm{Sz}, \mathrm{Ab}$ & 0 & 0,00 & 0 & 0,00 & 1 & 0,10 & 0 & 0,00 & 0 & 0,00 \\
\hline Number of species & & 52 & & 52 & & 57 & & 61 & & 43 & \\
\hline & & \multicolumn{10}{|c|}{84} \\
\hline Individuals- Total & & 1377 & 100,00 & 927 & 100,00 & 965 & 100,00 & 1493 & 100,00 & 1045 & 100,00 \\
\hline
\end{tabular}




\section{Table 2 (on next page)}

Results of the generalized linear model (GLM) of the analyzed transects and years when the observations were conducted, for the basic parameters describing the biodiversity of Carabidae assemblages in the analyzed area 
1

Tab. 2

\begin{tabular}{|c|c|c|c|}
\hline Species & $\overline{\mathrm{Df}}$ & Wald's Statistic & $\mathrm{p}$ \\
\hline Year & 4 & 90.99 & 0.00 \\
\hline Transect & 2 & 18.44 & 0.00 \\
\hline Year * Transect & 8 & 67.58 & 0.00 \\
\hline \multicolumn{4}{|l|}{ Individuals } \\
\hline Year & 4 & 287.81 & 0.00 \\
\hline Transect & 2 & 51.55 & 0.00 \\
\hline Year * Transect & 8 & 216.91 & 0.00 \\
\hline \multicolumn{4}{|l|}{ Shannon $\mathrm{H}^{\prime}$} \\
\hline Year & 4 & 25.14 & 0.00 \\
\hline Transect & 2 & 3.42 & 0.18 \\
\hline Year * Transect & 8 & 23.12 & 0.00 \\
\hline \multicolumn{4}{|l|}{ MIB } \\
\hline Year & 4 & 40.90 & 0.00 \\
\hline Transect & 2 & 879.70 & 0.00 \\
\hline Year * Transect & 8 & 12.20 & 0.14 \\
\hline
\end{tabular}

3 


\section{Table 3(on next page)}

Number of species, individuals and diversity index of carabids assemblages in the analyzed areas of Dąbrówka peat bog 
Tab. 3

2

\begin{tabular}{|c|c|c|c|c|c|c|c|c|c|c|c|c|c|c|c|c|}
\hline \multirow[t]{2}{*}{ Specification } & \multicolumn{3}{|c|}{2009} & \multicolumn{3}{|c|}{$2012 \_1$} & \multicolumn{3}{|c|}{$2012 \_2$} & \multicolumn{3}{|c|}{$2013 \quad 1$} & \multicolumn{3}{|c|}{$2013 \_2$} & \multirow{2}{*}{ Total } \\
\hline & A & B & $\mathrm{C}$ & A & $\mathrm{B}$ & $\mathrm{C}$ & $\mathrm{A}$ & $\mathrm{B}$ & $\mathrm{C}$ & A & $\mathrm{B}$ & $\mathrm{C}$ & A & $\mathrm{B}$ & $\mathrm{C}$ & \\
\hline Number of Individuals & 680 & 480 & 217 & 360 & 322 & 245 & 314 & 326 & 325 & 497 & 486 & 510 & 316 & 316 & 413 & 5807 \\
\hline Number of Species & 41 & 36 & 31 & 30 & 40 & 29 & 40 & 34 & 31 & 43 & 45 & 35 & 31 & 35 & 26 & 84 \\
\hline Shannon H' Diversity & 1,25 & 0,8 & 0,4 & 0,44 & 0,59 & 0,48 & 0,5 & 0,56 & 0,55 & 0,81 & 0,85 & 0,96 & 0,67 & 0,68 & 0,63 & - \\
\hline
\end{tabular}

3 


\section{Figure 1}

Approximate localization of the study sites $(\mathrm{I}, \mathrm{II})$, water retention reservoirs $(\mathrm{a}, \mathrm{b})$ and the transects set up in the research (A, B, C) Source: www.google.pl/maps, Olsztyn Forest District

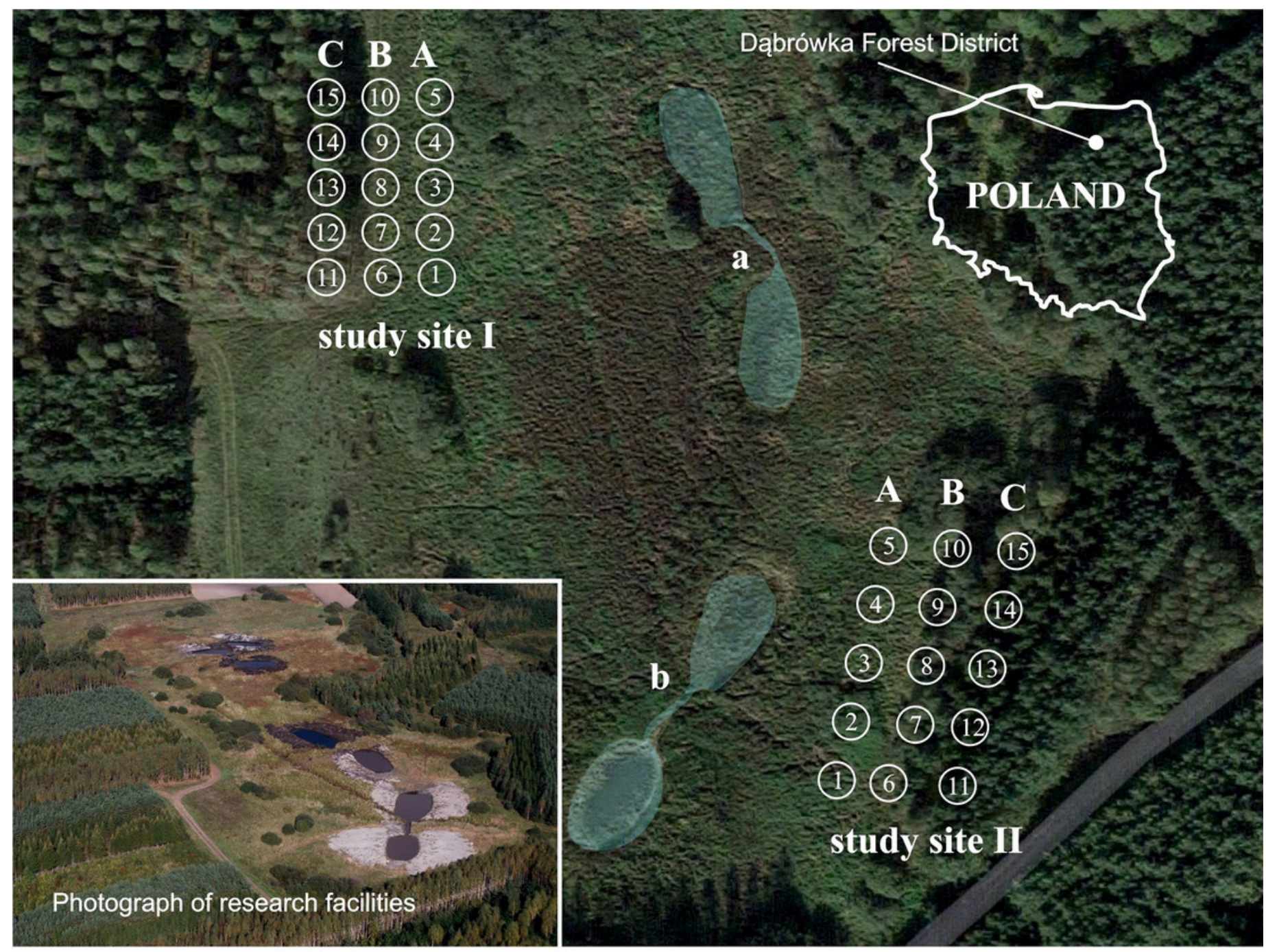


Figure 2

A, B, C. Mean values of species richness (a), abundance (b) and the MIB (c) in the analyzed transects and years of study, vertical lines with average mean SE 

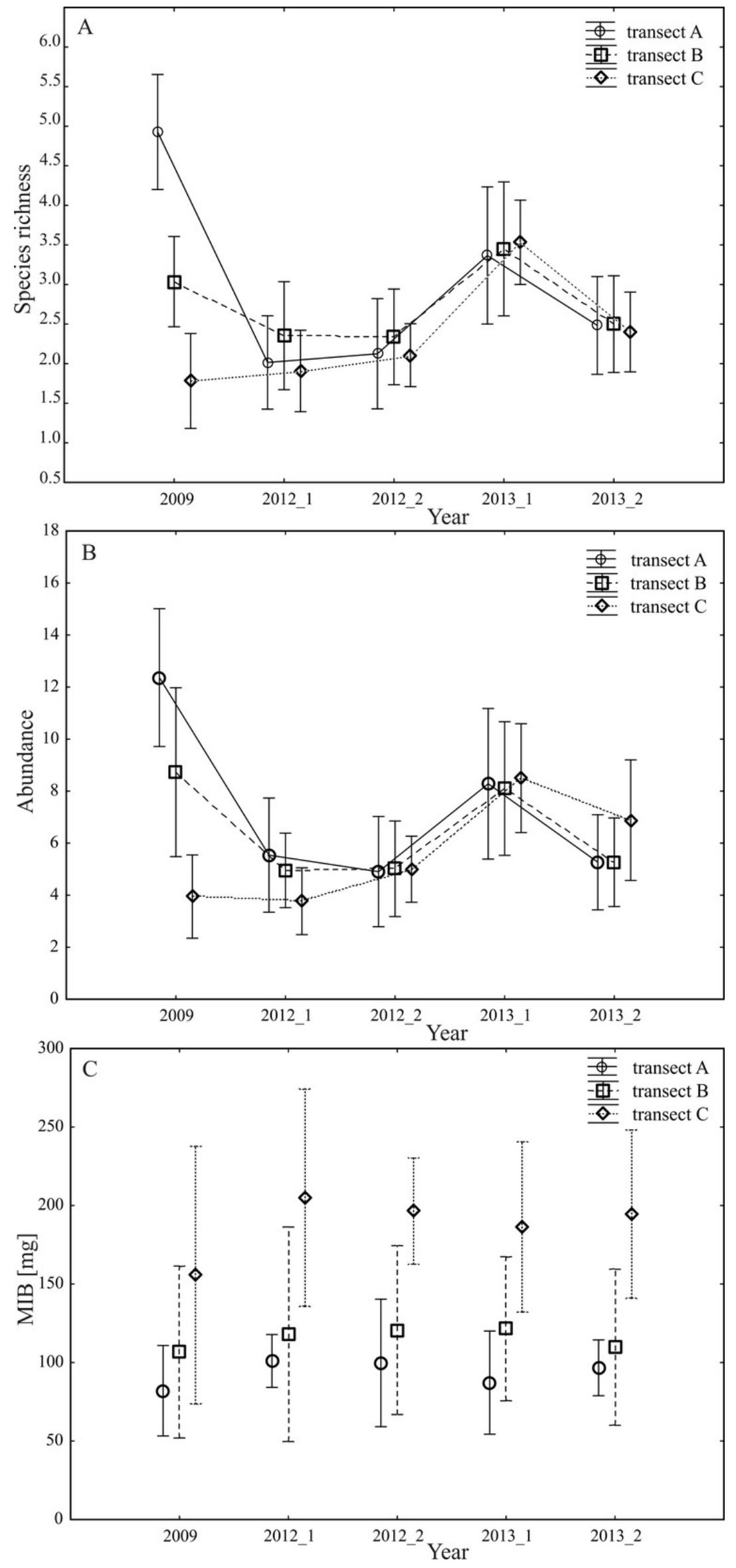

Peer) reviewing PDF | (2020:04:48069:2:0:NEW 2 Aug 2020) 
Figure 3

$A, B, C$. Expected number of carabid species caught in the studied sites using the Jackknife estimator ( \pm SD) of species richness (Species accumulation curves for carabid beetles assemblages sampled in three transects in years of study, using the Jackknife 

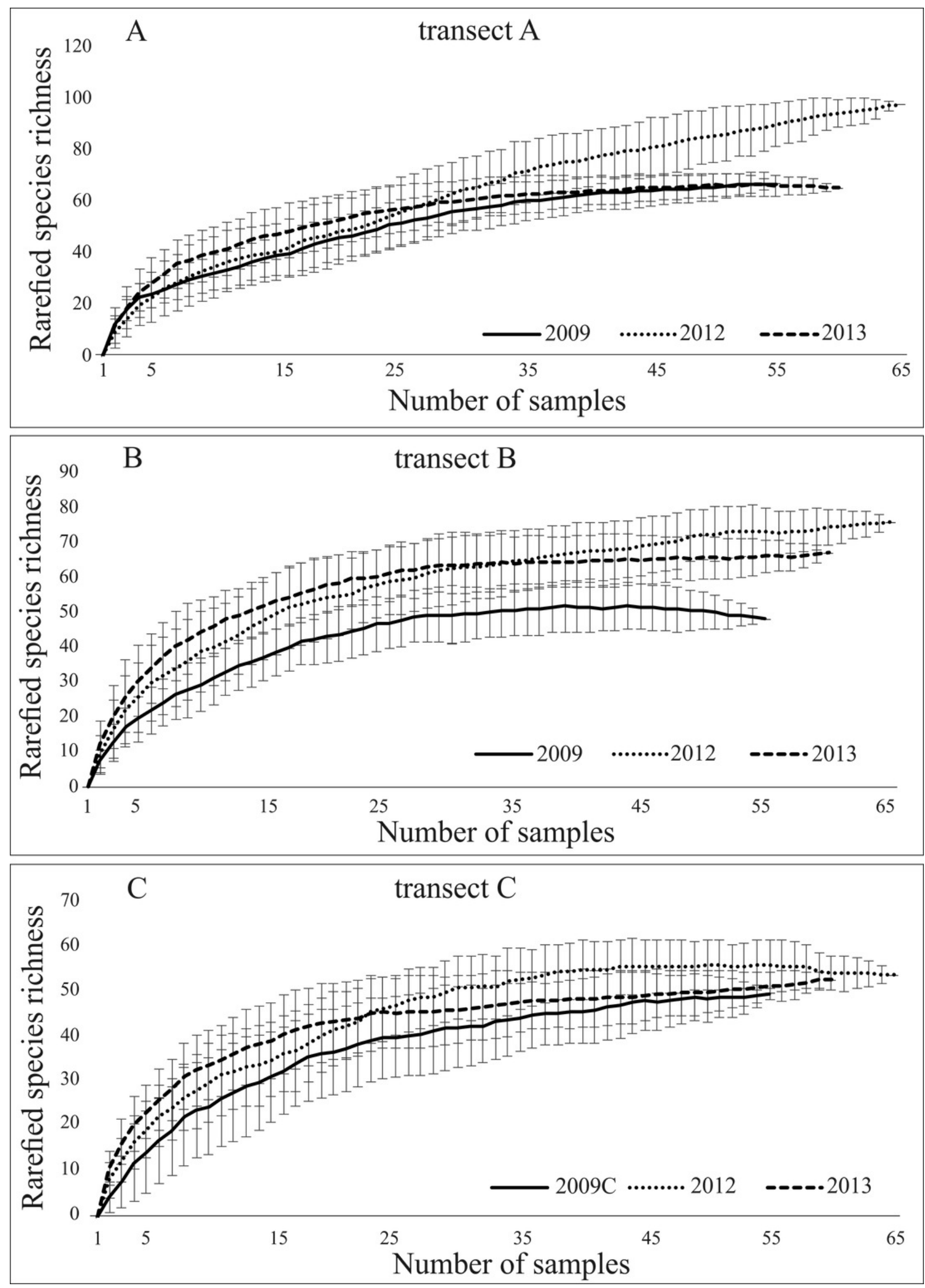
Figure 4

A, B, C. Diagram of the non-metric multidimensional scaling (NMDS) conducted based on the Morisita's similarity measure for the transects designated in the experiment $(A$, $B, C)$ 

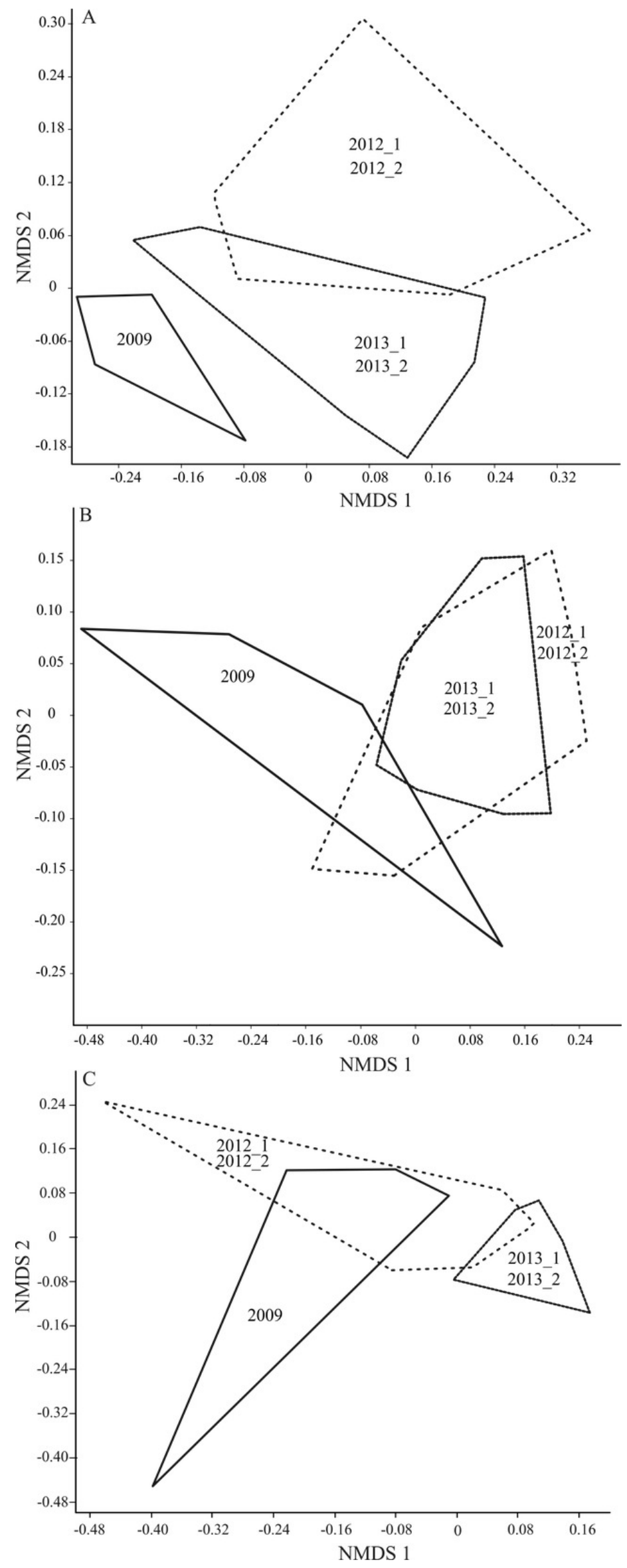

Peer) reviewing PDF | (2020:04:48069:2:0:NEW 2 Aug 2020) 
Figure 5

Diagram of the RDA analysis demonstrating the relationships between the analyzed environmental variables and Carabidae species in the studied sites. The abbreviation used on the graph are described in the chapter Materials \& Methods 


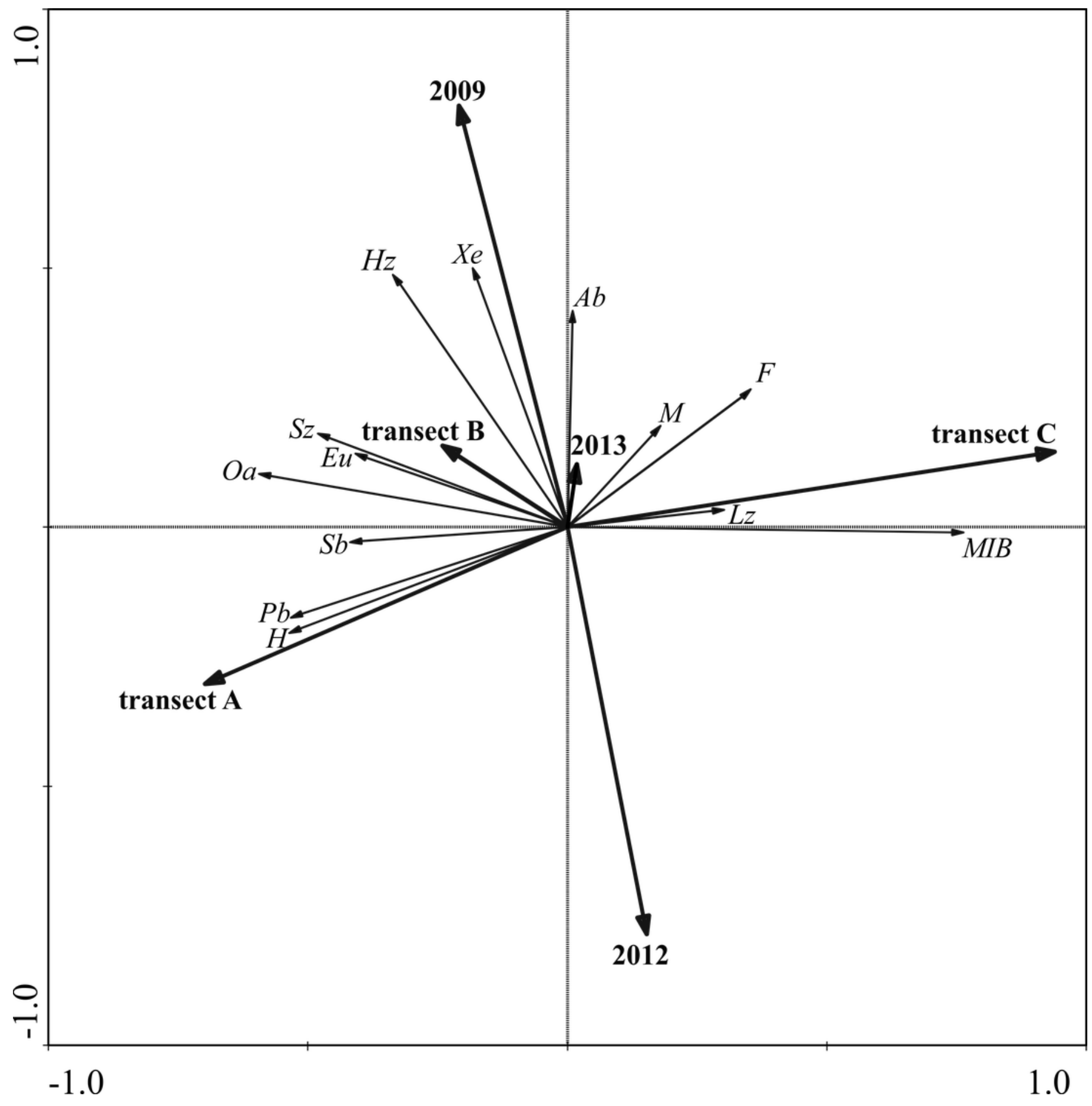

